Marquette University

e-Publications@Marquette

Economics Faculty Research and Publications

Economics, Department of

$12-1-2005$

Empirical Studies of Foreign Direct Investment

Joseph P. Daniels

Marquette University, joseph.daniels@marquette.edu

Accepted version. Atlantic Economic Journal, Vol. 3, No. 4 (December 2005): 381-382. DOI. (C) 2005 Springer Verlag. Used with permission.

Shareable Link. Provided by the Springer Nature SharedIt content-sharing initiative. 


\title{
Empirical Studies of Foreign Direct Investment
}

\author{
By Joseph P. Daniels*
}

Over the past two decades, foreign direct investment (FDI) flows have grown at remarkable rates, with outflows averaging over 28 percent a year from 1991 to 2000 alone [UNCTAD, 2004], greatly outpacing growth of exports. Though there has been a slowdown in FDI recently, it remains robust for many economies and appears to be poised for another surge in activity. FDI flows have also been changing, with greater flows going to developing economies and, remarkably coming from developing economies. In addition, flows are shifting from the manufacturing sector to service sectors and more attention is being paid to the outsourcing strategies of multinational enterprises. Hence, these FDI strategies, the determinants of FDI, and the impact of FDI on economic growth and development are prime subjects of empirical research. With support from the Institute for Global Economic Affairs at Marquette University, I am pleased to have the opportunity to organize the following symposium on Empirical Studies of Foreign Direct Investment for the Atlantic Economic Journal.

With numerous publications on foreign direct investment, Bruce Blonigen of the University of Oregon and research associate in the International Trade and Investment Program of the National Bureau of Economic Research is well suited to provide an opening article that surveys the empirical literature on the determinants of FDI. Blonigen breaks the survey into three sections, beginning with a review of the theory on firm-specific characteristics that drive FDI decisions. The bulk of his review then falls into the remaining sections on partial-equilibrium studies and general-equilibrium studies.

In the partial equilibrium section, Blonigen surveys the literature on exchange rates and exchange rate uncertainty, taxes, host-country legal institutions and corruption, trade policies, and scale and scope of trade relations as determinants of FDI. Because academic attention to FDI is relatively nascent, most of these issues remain unsettled, at least to differing degrees. The final section on general equilibrium approaches mainly focuses on the difficulties of modeling FDI decisions.

Blonigen points out the difficulties that exist in studying FDI determinants. At more than one point he acknowledges the lack of host-country and firm-specific data as a major obstacle. The interconnectedness of trade, investment, and corporate strategies is also acknowledged. Nonetheless, he provides ample motivation for further exploration, pointing out that most hypotheses on the determinants of FDI are "still up for grabs." He concludes that the most innovative papers in the area develop hypotheses about FDI determinants and then empirically 
test these hypotheses in a "creative" manner.

In "Following or Attracting the Customer? Japanese Banking FDI in Europe," Marc von der Ruhr of St. Norbert College and Michael Ryan of Western Michigan University follow Blonigen`s suggestion by first describing the "follow the customer" (FTC) hypothesis of FDI and then testing the hypothesis using Japanese banking data within a discrete choice model. In general, the FTC hypothesis proposes that the greater the home-based business FDI into a location, the more home service providers should FDI in that location. In other words, service FDI follows manufacturing FDI. The results of this study suggest that the relationship is much more complex in that banking FDI does occur after some non-banking presence is established, but also that greater banking FDI actually attracts additional non-banking FDI. von der Ruhr and Ryan conclude that policymakers seeking FDI inflows as part of a development strategy should liberalize their financial sectors so as to attract greater amounts of banking FDI and then, in turn, greater amounts of non-banking FDI.

In the third article, "Are Regional Concentrations of OECD Exports and Outward FDI Consistent with Gravity?" Walid Hejazi of the University of Toronto examines the argument of Alan Rugman and others that multinational enterprises tend to concentrate most of their activities regionally as opposed to globally (see Rugman [2000], as an example). Hejazi uses a gravity model as a benchmark to test if two decades of data on trade and FDI for a sample of OECD countries is consistent with gravity or show a greater regional concentration. He finds some support for the Rugman hypothesis in the case of European trade and FDI. For North America, however, intra-regional FDI is consistent with a gravity model. Hejazi concludes that the observed regional concentration in North American FDI data appears to be due to a "national bias" rather than a regional bias due to the large size of the U.S. market. In other words, once the national bias is included in the gravity model, a regional bias is no longer apparent.

In the final article "International Technology Diffusion: Effects of Trade and FDI," Alejandro Ciruelos and Miao Wang of Marquette University examine the impact of trade and FDI on technology diffusion. Past studies on the relationship between FDI and economic growth demonstrate that technological advance in a country may result from research-and-development capital stock diffusion via trade and FDI (see Hejazi and Safarian [1999], for example). Ciruelos and Wang make an important contribution to this area of research by allowing technology diffusion to occur through both channels simultaneously while distinguishing between developed nations and developing nations. One finding is that technology diffusion from FDI differs between developing and developed economies. The difference leads them to a noteworthy conclusion that developing nations need a minimum threshold of human capital to benefit from FDI-induced

\section{Daniels 2}


technology diffusion.

These papers benefited greatly from the comments of participants at the 2005 International Atlantic Economic Society and ASSA meetings. In particular, we thank Benjamin Liebman of St. Joseph`s University, Sunny Wong of the University of Southern Mississippi, and George Georgopoulis of York University. We also thank the Institute for Global Economic Affairs at Marquette University for not only sponsoring this activity but also providing support to Ciruelos, Wang and von der Rurh.

\section{Notes}

* Guest Editor, Marquette University-U.S.A.

\section{References}

Hejazi, Walid; Safarian, Edward. "Trade, Foreign Direct Investment and R\&D Spillovers," Journal of International Business Studies, 30, 3, 1999, pp. 491-511.

Rugman, Alan M. The End of Globalization, London: Random House, 2000.

UNCTAD. World Investment Report 2004: The Shift Towards Services, 2004, p. 2. 